Article

\title{
Climate Change and Increased Irrigation Demands: What Is Left for Hydropower Generation? Results from Two Semi-Arid Basins
}

\author{
Tor Haakon Bakken ${ }^{1,2, *}$, Christian Almestad ${ }^{1}$, Jørgen Melhuus Rugelbak ${ }^{1}$, Marisa Escobar ${ }^{3}$, \\ Steven Micko ${ }^{2}$ and Knut Alfredsen ${ }^{1}$ \\ 1 Department of Hydraulic and Environmental Engineering, Norwegian University of Science and \\ Technology (NTNU), S.P. Andersens veg 5, Trondheim NO-7491, Norway; \\ christian.almestad@multiconsult.no (C.A.); Jorgen.Rugelbak@ramboll.no (J.M.R.); \\ knut.alfredsen@ntnu.no (K.A.) \\ 2 SINTEF Energy Research, Sem Sælands vei 11, Trondheim NO-7465, Norway; stevejmicko@gmail.com \\ 3 Stockholm Environment Institute (SEI), Davis, CA 95616, USA; marisa.escobar@sei-us.org \\ * Correspondence: tor.haakon.bakken@sintef.no; Tel.: +47-9515-6944
}

Academic Editor: Juan Ignacio Pérez-Díaz

Received: 18 December 2015; Accepted: 4 March 2016; Published: 14 March 2016

\begin{abstract}
In this study, we have modelled the effect of climate change and increased irrigation withdrawals on the available water for hydropower production in two semi-arid river basins, i.e., Kizilirmak (Turkey) and Devoll (Albania), and the role of the reservoirs. The combined effect of climate change and extended irrigation withdrawals will overall lead to reduced runoff in the rivers, according to our simulations. The changes will be most dramatic at Kizilirmak, reducing the water available for hydropower production. The presence of the reservoirs will lead to extended water use/losses due to the provision of regulated flow, enabling larger irrigation withdrawals and increasing the evaporative losses from the reservoir surfaces. Comparing the water consumption losses at Kizilirmak, the irrigation losses are in the range of 2-4 times larger than the gross evaporation losses from reservoir surfaces. The reservoirs at Devoll will improve water availability for hydropower production during low flow periods, and the upstream irrigation represents presently a low risk to the downstream power producers. As the results are sensitive to specific river basin characteristics and the assumptions made, the results cannot be generalized to other river basins without taking these specifics into consideration.
\end{abstract}

Keywords: water availability; hydropower production; reservoirs; climate change; runoff; irrigation

\section{Introduction}

A growing population with increasing economic development and consumption lead to massive use of the Earth's resources [1], and recent calculations on freshwater consumption indicate global consumptive use beyond the freshwater planetary boundaries [2]. Many countries and regions experience water stress and aquatic ecosystems suffer from ecological degradation of, which is expected to increase and accelerate with climate change [3-5]. Due to global warming caused by anthropogenic greenhouse gas emissions, an increased share of renewable energy production is needed, and large-scale investments in solar, wind and hydropower are expected [4,6], possibly also having a direct positive effect on human health and reduced mortality [7]. Reservoirs are key elements and a prerequisite in water-stressed areas to secure adequate water services, such as water for irrigation, drinking water supply, flood control, navigation, as well as hydropower production [8,9].

Reservoirs typically store water from the wet to the dry season to provide adequate access to water year-round or to protect downstream areas from floods. As such, reservoirs decrease the temporal 
hydrological variability [10] in order to improve the availability of water in the dry season. On the other hand, reservoirs might also increase the total evaporation of water to the atmosphere and by this, reducing the annual runoff from a basin [11,12]. Finding the trade-offs of these two effects is a delicate balance and management task, as the economic benefits of the enhanced availability in the dry season might be enormous [13]. At the same time, the value of the lost water might also be very high [14]. In the case that reservoirs are used for hydropower production, these evaporative losses are denoted as the water consumption from hydropower production [15-17]. The specific water consumption values of hydropower production present a very inconsistent picture [4,17], from close to zero $\mathrm{m}^{3}$ /MWh [18] and even negative [19], to far beyond all other energy technologies $[4,16,17]$. The future with climate change, population growth, economic development and increased needs for food production stimulated by irrigation will add pressure on the available water resources [3]. The careful design, operation and management of the infrastructure to store and distribute water are hence a prerequisite and a challenge.

Furthermore, reservoirs play an important role for large-scale storage of energy [4]. With a gradual larger share of intermittent ("non-regulated") renewable energy production, such as solar and wind power $[4,20,21]$, the use of reservoirs for energy storage might be even more important in the future. Despite this, the global storage capacity is declining [22], as the siltation in existing reservoirs is larger than the building of new reservoir capacity, giving an even clearer declining trend when presented as storage capacity per capita.

Several studies have analyzed climate change and the long-term effect on runoff [3,23-26], as well as the changes in runoff variability [27]. Increased and decreased runoff, as well as increased variability will affect and possibly require increased storage capacity. Studies on the role of reservoirs in meeting society's needs for water in the context of climate change and increasing demands for irrigation are, however, missing. The overall objective of this study has been to analyze:

1. the effect of climate change and increased irrigation withdrawal on the mid- and long-term availability of water for hydropower production and other uses;

2. the role of reservoirs in maintaining the flow for multiple purposes.

This is illustrated in two semi-arid rivers in Turkey and Albania by imposing climate change predictions into a spatially-distributed hydrological model, defining likely scenarios for future irrigation withdrawals and by including/excluding reservoirs in the river basins from the model setups. Two control points, located at sites of hydropower plants, are selected for the assessments of the effects on the water resources available for hydropower production.

\section{Material and Method}

In order to answer the research questions, we assembled a set of methodologies to assess the objectives. First, we selected two study sites in Turkey and Albania with a reservoir present or under construction. Hydropower production provides one of several purposes, with competition over the water resource services. A hydrologic/water management modeling system was populated with data about the state of the river basins and historical climate data and calibrated against historical observations of runoff. A set of narrative scenarios for changes in climate and irrigation were defined and simulations carried out for future scenarios.

\subsection{Model Tool Applied: Water Evaluation and Planning Tool}

The WEAP software (Water Evaluation and Planning Tool) is a computer-based tool for integrated water resources planning and management, aimed at supporting policy-setting and decision-making [28]. WEAP supports multi-scenario-based planning for hydrologic basins and associated water systems related to drinking water supply, irrigation, hydropower production and multiple management objectives. The tool holds built-in algorithms for rainfall runoff and infiltration, evapotranspiration, crop water requirements and yields, surface water/groundwater interaction and 
instream water quality. Reservoir evaporation was calculated manually outside WEAP with the Penman-Monteith equation.

Various methods are available in WEAP to calculate the timing and volume of irrigation. The timing can be defined by fixed periods, water availability or the state of the soil water depletion. The volume of irrigation is either defined by fixed volumes set by the modeler or calculated by the degree of the soil water depletion.

Energy production is simulated in a very simplistic way compared to sophisticated, operational tools used by hydropower utilities, and optimization algorithms are not included in the software. For hydropower plants without reservoirs, the energy production is calculated based on water available in the river. In the case of reservoirs, the release of water for hydropower production can be set to meet a specific energy demand or simply by the availability of water, constrained by the turbine capacity. WEAP is now integrated with long range energy alternatives planning system (LEAP) [29], which supports more advanced analysis of the full energy system and its interdependencies with the water resources availability.

WEAP assumes that all flows occur instantaneously and that demand sites withdraw water from the river and consume it, returning the remainder after use, in the same time step. This way, all demands are covered depending on supply availability in the current time step. Given that there is no time lag considered, the model time step can be chosen based on the basin's size and residence time. As such, larger watersheds are represented with longer time steps on the order of months, while smaller watersheds are represented with shorter time steps on the order of days or weeks [28].

WEAP has a simplified geographical information system (GIS)-based interface, standard Windows dialogues and is equipped with powerful model-building capabilities allowing user-defined process descriptions to be incorporated.

\subsection{Case Study Descriptions}

The two case studies are located in a semi-arid region in the Mediterranean area (Figure 1). Kizilirmak River Basin is located in central Turkey, covers approximately $10 \%$ of Turkey by land area and drains into the Black Sea. The Devoll River Basin is located in Albania and is less than $1 / 20$ the size of the Kizilirmak River Basin. Details on the reservoirs are provided in Table 1 and river basin characteristics in Table 2.

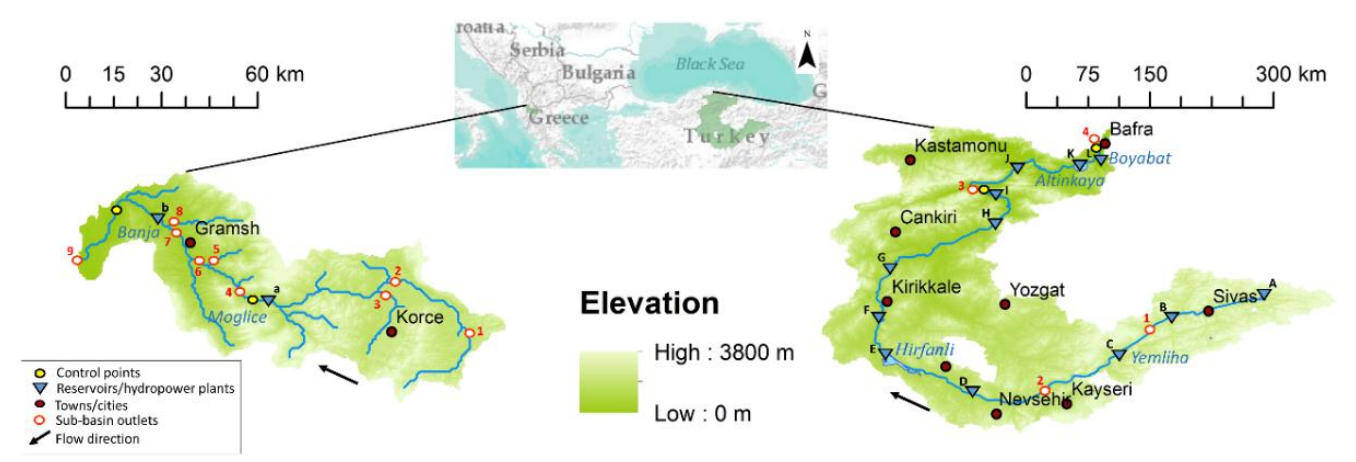

Figure 1. Case-study Devoll River Basin in Albania (left) and Kizilirmak River Basin, Turkey (right). The blue triangles are reservoirs; red rings with white fill indicate the outlet of a sub-basin in the model setups; the yellow circles are control points; dark red dots are towns/cities; and the black arrows indicate flow directions. Details on the reservoirs are provided in Table 1, further basin characteristics in Table 2.

During calibration (Section 2.4), only those reservoirs that are in operation/completed in the calibration period are represented in the model setups. During scenario simulations of the present and future situations (mid- and end of century), all of the reservoirs presented in Figure 1 and Table 1 
are simulated (see the details on the scenario definitions in Section 2.5). In those simulations without reservoirs, all reservoirs are removed from the model setups, in order to investigate the effect of the reservoirs on the water availability. At Devoll, both reservoir locations (Moglice and Banja) are used as control points, while Kargi and Derbent are used as control points at Kizilirmak (Section 2.4).

Table 1. Details on the reservoirs at Kizilirmak and Devoll River Basins. The coding in the first column refers to the coding used in Figure 1. The coding for this purpose is according to that used by international commission on large dams (ICOLD), where $\mathrm{H}$ is hydropower, I is irrigation, $\mathrm{S}$ is drinking water supply and $\mathrm{C}$ is flood control [8,30-32].

\begin{tabular}{|c|c|c|c|c|c|c|}
\hline $\begin{array}{l}\text { Code } \\
\text { in Map }\end{array}$ & $\begin{array}{l}\text { Reservoir } \\
\text { Name }\end{array}$ & $\begin{array}{l}\text { Storage Capacities } \\
\left(\mathrm{million} \mathrm{m}^{3}\right)\end{array}$ & Purpose & $\begin{array}{c}\text { Year in } \\
\text { operation }\end{array}$ & $\begin{array}{c}\text { Installed } \\
\text { Capacity }\left(\mathrm{m}^{3} / \mathrm{s}\right)\end{array}$ & $\begin{array}{c}\text { Installed } \\
\text { Capacity (MW) }\end{array}$ \\
\hline $\mathrm{a}$ & Moglice & 362 & $\mathrm{H}$ & 2018 & 65 & 173 \\
\hline$b$ & Banja & 391 & HI & 2016 & 93 & 70 \\
\hline A & Imranli & 62 & $\mathrm{IH}$ & 2003 & 40 & 18 \\
\hline B & Cermikler & 62 & $\mathrm{H}$ & 2013 & 110 & 25 \\
\hline $\mathrm{C}$ & Yemliha & 3476 & $\mathrm{IH}$ & 2005 & 123 & 52 \\
\hline $\mathrm{D}$ & Bayramha & 912 & $\mathrm{H}$ & 2011 & 135 & 47 \\
\hline $\mathrm{E}$ & Hirfanli & 5980 & $\mathrm{HI}$ & 1959 & 244 & 128 \\
\hline $\mathrm{F}$ & Kesilkopru & 95 & ISH & 1966 & 257 & 76 \\
\hline G & Kapulukaya & 282 & $\mathrm{SH}$ & 1989 & 165 & 54 \\
\hline $\mathrm{H}$ & Obruk & 661 & $\mathrm{IH}$ & 2009 & 375 & 211 \\
\hline I & Kargi & 40 & $\mathrm{H}$ & 2015 & 167 & 102 \\
\hline $\mathrm{J}$ & Boyabat & 3557 & $\mathrm{H}$ & 2012 & 471 & 528 \\
\hline $\mathrm{K}$ & Altinkaya & 5763 & $\mathrm{H}$ & 1988 & 676 & 703 \\
\hline $\mathrm{L}$ & Derbent & 213 & $\mathrm{HCI}$ & 1990 & 280 & 56 \\
\hline
\end{tabular}

Table 2. Characteristic values of the Kizilirmak and Devoll River Basins [30-36].

\begin{tabular}{ccc}
\hline Basin Information & Kizilirmak & Devoll \\
\hline Size of basin $\left(\mathrm{km}^{2}\right)$ & 78,200 & 3140 \\
Average flow at outlet $\left(\mathrm{m}^{3} / \mathrm{s}\right)$ & 186 & 46.6 \\
Basin-wide specific runoff $\left(\mathrm{l} / \mathrm{s} / \mathrm{km}^{2}\right)$ & 2.4 & 14.8 \\
Runoff coefficient $($ long term) & 0.16 & 0.50 \\
Average altitude (meters above sea level) & 749 & 960 \\
Altitude range (meters above sea level) & $0-3813$ & $22-2386$ \\
Range of average precipitation $(\mathrm{mm} /$ year) & $434-460$ & $660-1870$ \\
Population (2008) & 4.2 million & 302,000 \\
Population density (persons $\left./ \mathrm{km}^{2}\right)$ & 97.2 & 121.3 \\
Storage per catchment area (million $\left.\mathrm{m}^{3} / \mathrm{km}^{2}\right)$ & 0.27 & 0.24 \\
\hline
\end{tabular}

\subsection{Data for Model Setups}

The most important data for the configuration and calibration (Section 2.4) of the scenario simulations (Section 2.5) at the Kizilirmak and Devoll River Basins are climatic and hydrological data, river basin characteristics, information about the hydraulic infrastructure (reservoirs) and their operation, water use (irrigation) and the priority of water use in the basin. In order to calibrate the model, a period with all of these data available and of satisfactory quality had to be identified (Table 3). Due to the limited quantity of available data, the full dataset was used to calibrate parameter values. No data were set aside for validation purposes. The data used for calibration are described below.

Table 3. Data overview of Kizilirmak and Devoll River Basins as used in the model studies. Details on the sources of data are provided in $[30,31,36]$.

\begin{tabular}{ccc}
\hline Data Information & Kizilirmak & Devoll \\
\hline Climatic stations used & 2 & 17 \\
Runoff gauging stations used & 4 & 10 \\
Calibration period & $1981-2003$ & $1980-1985$ \\
Time resolution calibration/simulations & Monthly & Daily \\
\hline
\end{tabular}


Runoff data: Data on runoff were used to calibrate the model setups and were provided by Statkraft. The level of quality control was considered adequate, and no further processing, such as error corrections, or temporal, or spatial interpolation of the data, was made. Details are provided in [30,31].

Climatic data: At Kizilirmak River Basin, data on climate were provided by the national climatic data center (NCDC). In this basin, data were available from only two climatic stations, which were assigned to the sub-basins based on an inverse-distance approach. Climate data in the Devoll watershed were provided by Statkraft. Spatial representation of the climatic data was made by Thiessen polygons [37]. In both basins, the received data were of adequate quality, and no further processing was needed. In the case of data gaps (missing data), these periods were simply excluded. Details are provided in $[30,31]$. Details on climatic data used in the scenario simulations of mid-and end of century situations are given in Section 2.5.

Irrigation data/withdrawal: Data on water withdrawal for irrigation at Kizilirmak were provided by Statkraft/SERGROUP Consultancy Company and the Turkish authorities (DSI (The General Directorate of State Hydraulic Works)). Irrigation data for Devoll were based on data in [34], information provided by Statkraft, communication with local experts and a site visit. The irrigation withdrawal was given with a periodicity, where the irrigation in both basins starts in April, gradually increases to a maximum in July and decreases until October. No irrigation occurs in the period of the months from November to March. The irrigation data (timing, volume) are considered uncertain. Details on the volumes of irrigation per sub-basins used in each scenario simulations are given in Section 2.5.

Reservoir data and energy demand: Data on the reservoirs, hydropower operations and the energy demand at Kizilirmak and Devoll were provided by the hydropower utility Statkraft and [24]. At Kizilirmak, energy demands for each hydropower power plant and release from the reservoirs made in order to fulfill demands are defined each time step. At Devoll, releases for power production are made when water is available. This is a very simplistic approach to operating hydropower plants and introduces uncertainties in the results. For this reason, the results on energy production and energy demand fulfillment are not included in the paper.

Priorities: WEAP allows the modeler to define priorities for various water uses, i.e., high priority use will reach demand fulfillment before low priorities. The priorities at Kizilirmak are defined in consecutive order from upstream to downstream, i.e., the water uses in the upper part fulfill their needs first, if water is available. At Devoll, all demand sites are given equal priority, except the environmental restrictions in the mid- and end of century scenarios, which are given highest priority. Therefore, a relatively equal deficit will be imposed on all demands in periods of limited supply

In the case of the Kizilirmak River Basin, a monthly time step was used to represent the larger residence time of the basin. The Devoll River Basin uses a daily time step to account for the shorter residence of water in this smaller watershed (see Section 2.1 for details on handling the time lag).

\subsection{Calibration Approach and the Assessment of Water Available for Hydropower Production}

The purpose of the calibration is to adjust the free and semi-physical parameters in the model to reproduce the observed values of runoff in the best way possible. A well-calibrated model is expected to simulate changes in the system with reasonable accuracy.

In order to estimate model performance, the goodness of fit was quantified and evaluated with two different statistical criteria: percent bias (PBIAS) and Nash-Sutcliffe efficiency (NSE), both described by, e.g., [38]. PBIAS is used to compare the annual and monthly water balance of the observations with the simulation results, and positive PBIAS values indicate that the model over-estimates the observed values. NSE is more sensitive to errors in timing of the modelled flow than PBIAS.

Two control points in each of the river basins were used to analyze the effects of climate change, irrigation withdrawals and reservoirs. A control point is a location in the basin where results are of special interests. These points might coincide with where observations are made, the location of a power plant or where the effect of a change in the basin is of particular concern. In our case studies, these points are at the outlet of the river basins and in the middle, lower section of the basins (Figure 1). 
In the case of Kizilirmak, the middle, lower location is close to Kargi hydropower plant. Kargi is downstream from the Hirfanli and Yemliha reservoirs, but upstream of the Altinkaya and Boyabat reservoirs. At Devoll, the middle, lower location is in between the two reservoirs, i.e., downstream of the Moglice reservoir and upstream of the Banja reservoir. The effect of the reservoirs on the available water resources for hydropower production and other uses is studied with the means of flow duration curves, which is further measured against the percentage of time the water flow is equal to the installed turbine capacities at the power plants selected for comparison (Table 1).

\subsection{Definition of Scenarios}

Model scenarios were defined for three different time horizons, i.e., today/present situation, mid-century and end of century. Predictions on future changes in climate and irrigation withdrawals were compiled from publicly-available sources, which are detailed and quantified in Tables 4 and 5.

Table 4. Description of climatic input to scenario simulations, with and without reservoirs. The climate scenarios are based on the median values from RCP4.5 [39]. The means of: Temp. = temperature change in ${ }^{\circ} \mathrm{C}$; Prec. = precipitation change in percent. The first numbers indicate the change during the summer, while the numbers after refer to the winter period for Kizilirmak. In the case of Devoll, the temperature changes are given as annual averages. The modelled scenarios are a combination of changes in climate (this table) and changes in irrigation withdrawals (Table 5). S, summer; W, winter. Representative concentration pathway: RCP. Ann. ave = annual average.

\begin{tabular}{ccccc}
\hline River Basin & Climatic Variable & Present & Mid-Century & End of Century \\
\hline Kizilirmak & Temp. & As observed & $+2.5 /+1.5{ }^{\circ} \mathrm{C}(\mathrm{S} / \mathrm{W})$ & $+3 /+2{ }^{\circ} \mathrm{C}(\mathrm{S} / \mathrm{W})$ \\
& Prec. & As observed & $-5 \% /-2.5 \%(\mathrm{~S} / \mathrm{W})$ & $-10 \% /-5 \%(\mathrm{~S} / \mathrm{W})$ \\
\hline \multirow{2}{*}{ Devoll } & Temp. & As calibration period & $+1.9{ }^{\circ} \mathrm{C}($ ann. ave) & $+2.4{ }^{\circ} \mathrm{C}($ ann. ave) \\
& Prec. & As calibration period & $-15 \% /-10 \%(\mathrm{~S} / \mathrm{W})$ & $-20 \% /-10 \%(\mathrm{~S} / \mathrm{W})$ \\
\hline
\end{tabular}

Table 5. Description of irrigation demands used as input to scenario simulations. At Kizilirmak, the present situation refers to those irrigation schemes built by 2013 (in all sub-basins) and the mid-century situation as given by plans for extensions of the irrigation system. The end of century withdrawals are the same as the mid-century. At Devoll, the present situation is given by the current status of the irrigation system, while both the mid- and end of century introduce rehabilitation/extension in the upper parts. The numbers are given in mill. $\mathrm{m}^{3} /$ year $\left(\mathrm{m}^{3} / \mathrm{s}\right.$ in parenthesis) are total volumes (average annual flow) for the whole irrigation period. A periodicity according to the description provided in Section 2.3 is applied on the volumes given.

\begin{tabular}{cccc}
\hline River Basin & Sub-Basin & Present & Mid-Century (End of Century) \\
\hline Kizilirmak & 1 & $80.8(2.6)$ & $128.7(4.1)$ \\
& 2 & $124.0(3.9)$ & $159.5(5.1)$ \\
& 3 & $871.7(27.6)$ & $1392.4(44.2)$ \\
& 4 & $222.6(7.1)$ & $352.2(10.1)$ \\
\hline Devoll & $1-3$ & $53.8(1.7)$ & $75.2(2.4)$ \\
& 4 & $6.8(0.2)$ & 0 \\
& $5-8$ & $6.3(0.2)$ & 0 \\
\hline
\end{tabular}

* Irrigation withdrawals downstream of Banja reservoir are excluded from these numbers.

All three time horizon scenarios were run for both the situation with reservoirs and with all reservoirs removed from the model setup, in order to analyze the effects of the reservoirs on water availability. No new reservoirs are introduced into the model setup of the present situation. The midand end of century scenarios at Kizilirmak are model simulations for the periods of 2050-2055 and 2085-2090, while the mid- and end of century scenarios at Devoll are 2065-2070 and 2100-2105, respectively. The length of the simulation period ( 6 years) was determined by the combined requirements of available climatic data and reliable information about the state and operation of the reservoirs and the irrigation system. 
The predictions for changes in climate are based on the scenarios given by [39]. The values are based on the fairly modest RCP4.5 (representative concentration pathway) emission scenario, median values and diversified for summer $(\mathrm{S})$ and winter $(\mathrm{W})$ or a finer temporal resolution when available (month). The changes in precipitation and temperature are based on the "delta change" method $[40,41]$. The delta changes are computed based on the difference between the historical simulation from the GCM (global circulation models) and the future GCM scenarios, with an additive factor for temperature and a multiplicative factor for precipitation. The present climate is assumed to be identical to the climate given in the calibration periods of the two cases. This is considered to be a reasonable assumption given the fact that the IPCC scenarios for future climate change [39] are based on the reference period 1986-2001 (calibration periods given in Table 3). In the case of Devoll, the calibration period is slightly outside the reference period of the climate change scenarios [39], due to the reason that the irrigation data were considered more reliable in these periods than in the late 1980s and 1990s, when the irrigation system and the monitoring started falling apart. Only one climate change scenario was selected, as the purpose of the study was to assess the combined effect of both the change in climate and irrigation withdrawal, as well as the effect of the reservoirs.

The data on water withdrawals for irrigation for the Kizilirmak are based on the present withdrawal of water. The mid-century withdrawals are based on publicly-available plans for further development of irrigation schemes, provided by the Turkish authorities (Turkish DSI). The defined irrigation withdrawals at the end of the century assume that the irrigation withdrawals stays at the same level as mid-century.

As the reservoirs at Devoll are currently under construction, the model was calibrated on historical data without reservoirs in the river basin. The introduction of reservoirs in the model setup under present conditions is hence a scenario analyzing the possible effects on water availability if the reservoirs had been in place already today (by 2015). In the simulations of the mid- and end of century situations, the reservoirs are assumed in operation. In order to analyze the effect on the water availability, these reservoirs are also removed from the future simulation. In the case of Kizilirmak, all of the reservoirs are assumed to be built and no new ones to be added. The future scenarios are simulated with and without the existing reservoirs.

There will be future restrictions on the release of water from the two reservoirs at Devoll under construction. These restrictions are imposed on the future scenario simulations in Albania (but not in the "present" scenarios) and set to a constant flow of $1 \mathrm{~m}^{3} / \mathrm{s}$ and $2 \mathrm{~m}^{3} / \mathrm{s}$ at Moglice and Banja, respectively. It should also be noted that Banja has agreed to release 150 million $\mathrm{m}^{3}$ of irrigation water between May and August, which represents a formalization of the historic/present irrigation in the very lower part of the basin. This will result in a peak flow of $32 \mathrm{~m}^{3} / \mathrm{s}$ in July, which may affect the power production. There are no defined restrictions related to environmental flow releases in Turkey.

The modelled scenarios are a combination of predicted changes in climate (precipitation and temperature), as given in Table 4, and the changes in irrigation, as defined in Table 5. The scenario simulations are carried out for the present situation, mid-century and end of century situation in both Kizilirmak and Devoll. These six scenarios are all further split into two different variants, i.e., with all reservoirs present in the model setups and without any reservoirs in the model setups, in order to investigate the effect of the reservoirs on the water available for hydropower production and other use. The scenarios without reservoirs present in the model setups are simply generated by removing these objects from the WEAP setups.

\section{Results and Discussion}

\subsection{Calibration Performance}

According to [42], calibration results based on simulations with monthly time steps are considered "very good" if PBIAS is less than $\pm 10 \%$, and good if between $\pm 10 \%$ and $\pm 15 \%$. NSE values less than zero indicate that average values are better predictors than model simulations. As our study mostly considers the mid- and long-term changes of the water balance and availability and emphasized 
temporal accuracy less, the performance of PBIAS was considered most important. The calibration results are presented in Table 6.

Table 6. Calibration of runoff and statistical performance according to the percent bias (PBIAS) and Nash-Sutcliffe efficiency (NSE) criteria, at selected locations in each of the basins. Positive PBIAS values indicate over-estimation by the model (see the details in Section 2.4).

\begin{tabular}{ccccccccc}
\hline Basin & \multicolumn{4}{c}{ Kizilirmak River Basin } & \multicolumn{3}{c}{ Devoll River Basin } \\
\hline Statistical Criteria & $\mathbf{1}$ & $\mathbf{2}$ & 3-Kargi & 4-Derbent & $\mathbf{3}$ & $\mathbf{4}$ & 8-Moglice & 9-Banja \\
\hline PBIAS (\%) & 4.5 & -8.9 & -17.3 & -2.3 & -7.9 & 6.1 & 1.4 & -3.1 \\
NSE & 0.91 & 0.46 & 0.20 & 0.53 & 0.25 & 0.42 & 0.30 & 0.47 \\
\hline
\end{tabular}

The calibration statistics for Kizilirmak are based on a sub-set of the calibration period (Table 3). The first years (1981-1982) are problematic due to large uncertainties in the initial state of the whole system, in particular the filling of the reservoirs. For this reason, the years 1981-1982 are excluded from the calibration statistics, but the period is still used to "warm up" the model. Inaccurate representation of filling/release of water during situations, for instance related to construction of reservoirs, will in particular affect the performance of NSE, which is very sensitive to the temporal performance of the model simulations. The period where the large Altinkaya reservoir at Kizilirmak is filled (years 1988-1989) (Table 1) is for this reason excluded from the NSE statistics. The low performance with respect to NSE can also be explained by a combination of the selected temporal resolution, size of the catchment and the fact that WEAP does not do flow routing or time lags in the river (Section 2.1).

In the case of Devoll, simulation results from all years are kept in the statistics, and the possible challenges related to filling of the reservoir are not present during the calibration period, as this is prior to the construction of the reservoirs. It should also be noted that there might be errors in the observations of runoff.

\subsection{Changes in Mid-and Long-Term Annual Flow Values}

The simulated future scenarios are based on reduced precipitation, increased temperatures and enhanced irrigation withdrawals in both basins (Tables 4 and 5). The results show that the average annual runoff will decrease in the future at both control locations in both river basins, with and without reservoirs present (Figure 2). The relative future change in runoff is largest at Kizilirmak, where the reductions are in the range of $32 \%-46 \%$ with reservoirs present in the basin and in the range of $21 \%-28 \%$ without reservoirs, when compared to the present situation. The reductions are largest in the end of century simulations, and the relative change is largest at the middle, lower location (Kargi hydropower plant (HP)). The reductions in flow at Kizilirmak are explained by the combined effect of reduced precipitation, increased evapotranspiration and reservoir evaporation (when reservoirs are present in the model setup) and increased withdrawal for irrigation, enabled by the regulated flow provided by upstream reservoirs.

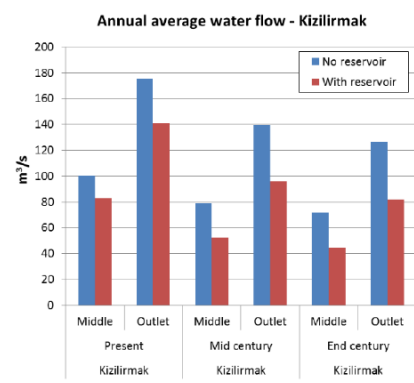

(a)

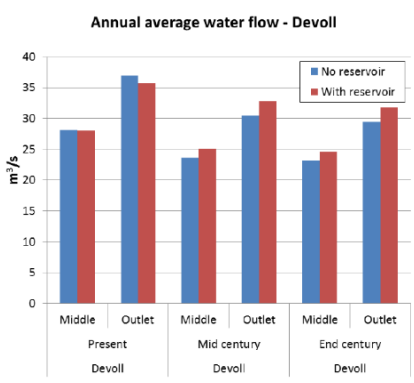

(b)

Figure 2. Average annual water flow at the middle lower and outlet control points, for the present, midand end of century situation, with and without reservoirs. The results from Kizilirmak are presented to the (a) and Devoll to the (b). 
The reductions in runoff from climate change scenarios are relatively smaller at Devoll than Kizilirmak, i.e., in the range of $16 \%-20 \%$ without reservoirs and $9 \%-12 \%$ with reservoirs in the basin, all compared to the present situation (Figure 2). The largest reductions are in the end of century scenarios. A combination of factors leads to the more modest reductions at Devoll. Environmental flow restrictions downstream of Moglice and Banja are introduced in the mid- and end of century simulations. These releases combined with the water demands for power production at the same sites affect the upstream water use, as the environmental flow and power production are all given high or equal priorities for water allocation, giving limitations to the water withdrawal in the upstream areas. Furthermore, in the mid- and end of century scenarios, the irrigation in the middle part of Devoll is abandoned, as these irrigation schemes are considered not viable in the future and will hence reduce the withdrawal. The model results indicate increased potential evapotranspiration, but leading to only a marginal increase in actual evapotranspiration, as the evapotranspiration is constrained by the soil moisture content.

\subsection{Changes and Effects in Water Use and Losses}

The irrigation withdrawals, as well as the evaporation losses from the reservoirs are much larger at Kizilirmak than Devoll (details in Figures 3 and 4). The evaporation losses are largest in Sub-basin 3 at Kizilirmak, where the largest reservoir (Hirfanli) is located. The evaporative losses increase with increased temperatures due to climate change. The irrigation withdrawals at Kizilirmak are larger than the losses due to reservoir evaporation, typically 2-4 times larger, when reservoirs are present in the model setups (Figure 3). The regulated flow provided by the reservoirs enables larger irrigation withdrawals, and this effect can be seen in all sub-basins in all scenarios, except the most downstream, where the irrigation demand is also fulfilled in the unregulated situation (Table 7). At Devoll, the losses due to reservoir evaporation and irrigation withdrawals are limited in all scenarios (Figure 4).

Table 7. Irrigation demand fulfillment (coverage) for the future scenarios and sub-basins. The demand fulfillments are given as average numbers for the whole simulation periods and vary between the individual irrigation schemes, during the irrigation period (April-October), as well as from year to year. "Res." refers to a situation with reservoirs in the basins, while "No Res." refers to a situation where the reservoirs are removed. The numbers are given in $\%$.

\begin{tabular}{cccccccc}
\hline \multirow{2}{*}{ River Basin } & \multirow{2}{*}{ Sub-Basin } & \multicolumn{2}{c}{ Present } & \multicolumn{2}{c}{ Mid-Century } & \multicolumn{2}{c}{ End of Century } \\
\cline { 2 - 7 } & & Res. & No Res. & Res. & No Res. & Res. & No Res. \\
\hline \multirow{2}{*}{ Kizilirmak } & 1 & 100 & 98 & 81 & 76 & 78 & 70 \\
& 2 & 100 & 100 & 98 & 74 & 96 & 68 \\
& 3 & 100 & 82 & 100 & 65 & 100 & 63 \\
& 4 & 100 & 100 & 100 & 100 & 100 & 100 \\
\hline \multirow{2}{*}{ Devoll } & $1-3$ & 74 & 74 & 36 & 49 & 21 & 47 \\
& 4 & 100 & 86 & N/A & N/A & N/A & N/A \\
& $5-8$ & 88 & 77 & N/A & N/A & N/A & N/A \\
& 9 & 100 & 100 & N/A & N/A & N/A & N/A \\
\hline
\end{tabular}

During the present situation at Devoll, the annual water flow is lower with reservoirs than without (Figure 2, right side). This is explained by reservoir evaporation and to, a lesser extent, irrigation withdrawals (Figure 4). The effect of irrigation is limited, as the majority of the irrigated fields are located upstream of the uppermost reservoir and will hence not benefit from the regulated flow. There are also irrigation withdrawals downstream of the Banja reservoir, but these are downstream of the control points and, hence, not captured by the numbers presented in Figure 4 . In the mid- and end of century simulations, the situation changes, and the average annual flow is larger with reservoirs than without, which is also opposite the results at Kizilirmak (Figure 2). This change is explained by the water allocation priorities set in the model. The introduction of the Banja and Moglice reservoirs, including environmental flow restrictions in the very lower end, changes the priority of the water use 
in the basin. This will restrict the withdrawal for irrigation in the upper part (Figure 4 and Table 7) (leading to lower irrigation coverage) and, hence, increase the flow in the lower parts of the basin.

Table 7 presents the coverage/demand fulfillment of irrigation water for the various scenarios in both basins. The reservoirs at Kizilirmak clearly increase the demand coverage in all situations, while the reservoirs at Devoll and the introduction of environmental flow requirements in the lower parts of the basin reduce the irrigation demand fulfillment. At Kizilirmak, it can also be seen that the lower parts with the highest degree of regulation (Table 7, Figure 1 and Table 2) obtain a higher demand coverage than the upper parts with less regulation.

It should also mentioned that water is withdrawn from the basin for irrigation purposes downstream of the Banja reservoir. This withdrawal does not affect the power production upstream, but does explain the reduced flow from the outlet of Sub-basin 8 to the outlet of Sub-basin 9 (Figure 4).

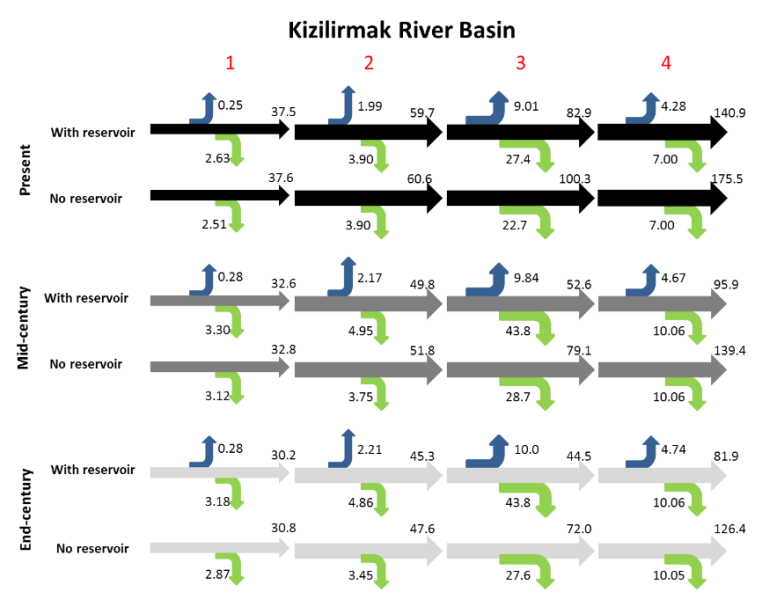

Figure 3. Spatial distribution of water losses/withdrawals at Kizilirmak River Basin during present, mid-century and end of century situations, with and without reservoirs. The horizontal arrows indicate water flows in the river; arrows pointing upwards sum evaporative losses from reservoir surfaces, and arrows pointing downwards water withdrawals for irrigation. The results are presented per sub-basin (red numbers on top), and the numbers are given as average annual water flows $\left(\mathrm{m}^{3} / \mathrm{s}\right)$.

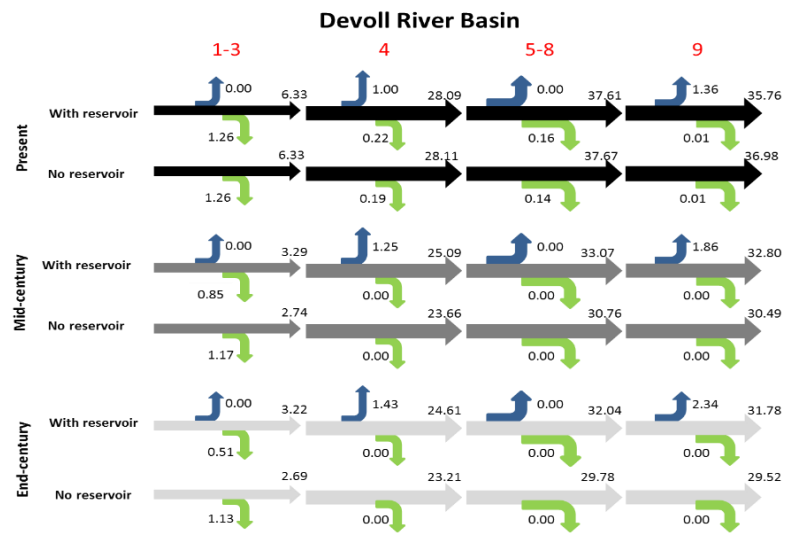

Figure 4. Spatial distribution of water losses/withdrawals at Devoll River Basin during present, mid-century and end of century situations, with and without reservoirs. The horizontal arrows indicate water flows in the river; arrows pointing upwards sum evaporative losses from reservoir surfaces and arrows pointing downwards water withdrawals for irrigation. The results are presented per sub-basin (red numbers on top), and the numbers are given as average annual water flows $\left(\mathrm{m}^{3} / \mathrm{s}\right)$.

\subsection{Effects on the Flow Duration Curves and Turbine Utilization Time}

The results from Kizilirmak, presented as flow duration curves (Figure 5), show that reservoirs clearly improve the water availability during low flow periods under the present situation at both 
control locations (Figure 5, uppermost panels). The increased availability is most pronounced in the middle, lower control point (Kargi), as this is downstream of the large Hirfanli and Yemliha reservoirs and upstream of areas with extensive irrigation. In the control point at the outlet, the same effect of increased availability can be seen, but is more modest. By the mid- and end of century, the effect on the elevated low flows is gradually reduced and can hardly be seen, especially at the outlet location. The high flows are reduced in both locations under present, mid-century and end of century conditions (Figure 5).

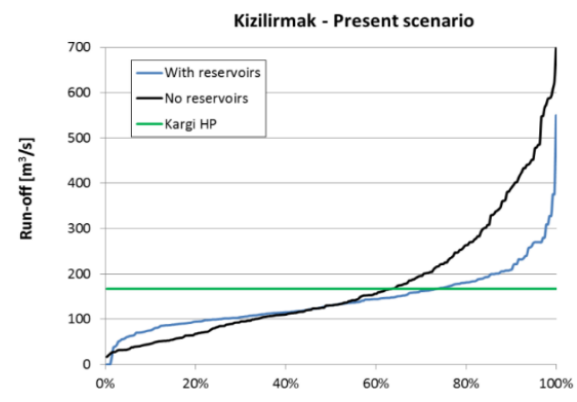

(a)

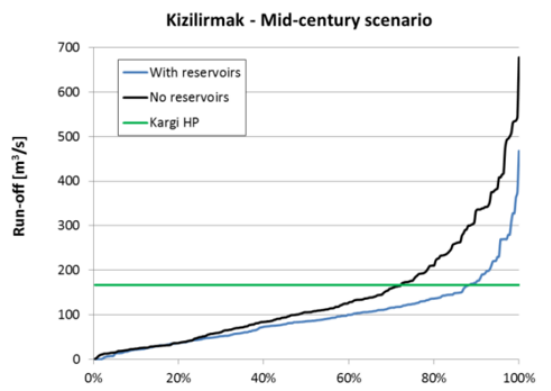

(c)

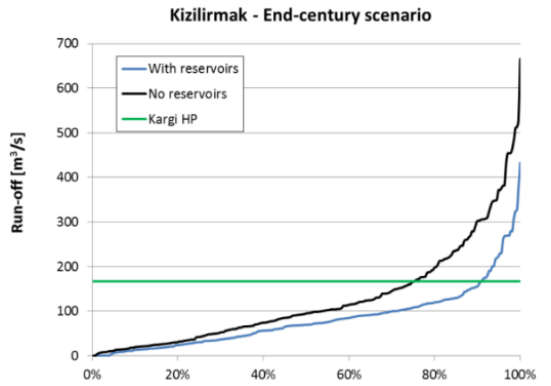

(e)

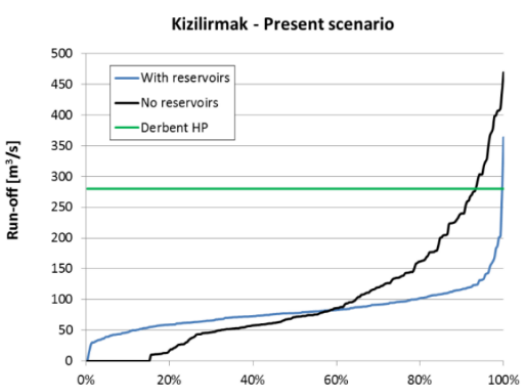

(b)

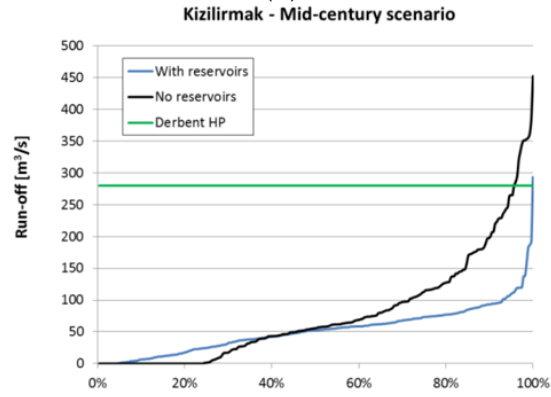

(d)

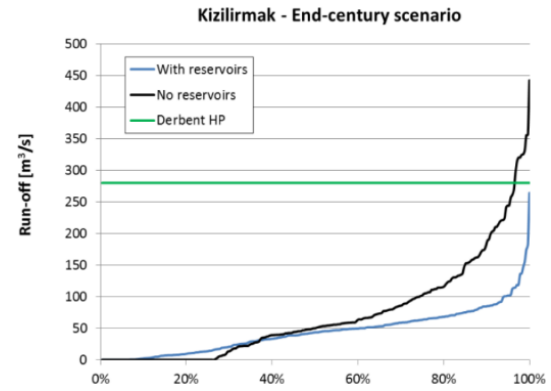

(f)

Figure 5. Scenario results presented as flow duration curves (exceedance curves) from Kizilirmak River Basin, under present, mid-century and end of century climatic conditions and irrigation withdrawals as specified in Tables 4 and 5 with and without reservoirs present. The horizontal lines represent turbine capacities of the hydropower plants located close to the control points. $(\mathbf{a}, \mathbf{b})$ refer to present situation at the middle, lower control point and close to the outlet, respectively. $(\mathbf{c}, \mathbf{d})$ present results from the mid-century situation at the same control locations, while $(\mathbf{e}, \mathbf{f})$ refer to the end-century situation at the middle, lower control point and close to the outlet, respectively.

At the location of Kargi HP, the upstream reservoirs improve the availability of water (Figure 5, left panels), as shown by the light blue line "with reservoirs" being above the black line "no reservoirs" in periods of low flow. Approximately $65 \%$ of the time during the present situation, $50 \%$ of the time during the mid-century situation and approximately $40 \%$ of the time by the end of the century, higher availability is expected in low flow periods. At the outlet, the reservoirs improve the water availability about $40 \%$ of the time during the present situation, while no improvements can be found in the future simulations (Figure 5, right panels). Unexpectedly, the flow values starting from approximately half the turbine capacities at Kargi HP and Derbent HP are reduced by the introduction of the reservoirs 
(Figure 5). This is due to the high irrigation demand between the reservoirs and power plants. This demand consumes the increased availability of water provided by the Hirfanlie and Yemliha reservoirs. The regulated flow enables these schemes to withdraw more water than without the reservoirs, giving higher irrigation demand coverage than without reservoirs (Table 7). The increased evaporation from the upstream reservoirs also contributes to the lowered volumes of water available for power production. To what extent the power production can benefit from the periodically increased flows will depend on the span/range of operation of the installed turbines.

The flow duration curves at Devoll (Figure 6) do not differ very much in the situation with or without reservoirs, except the cap on the Banja curves (Figure 6, right part), which indicates the level where power production is on maximum turbine capacity $\left(90 \mathrm{~m}^{3} / \mathrm{s}\right)$. The specified energy demand is met at this level, and surplus beyond this flow level starts filling the reservoir.

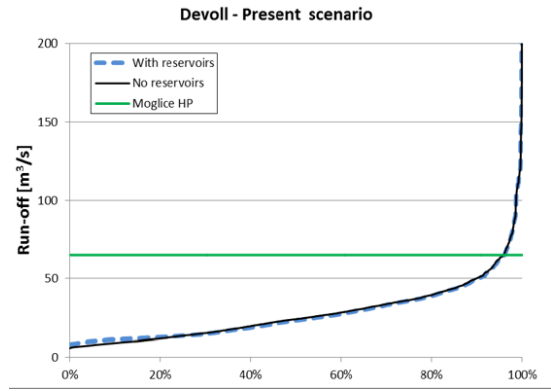

(a)

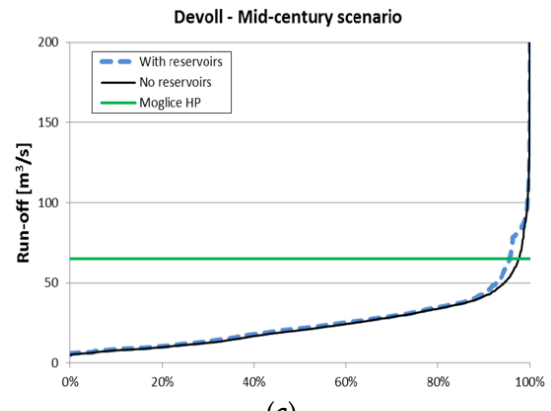

(c)

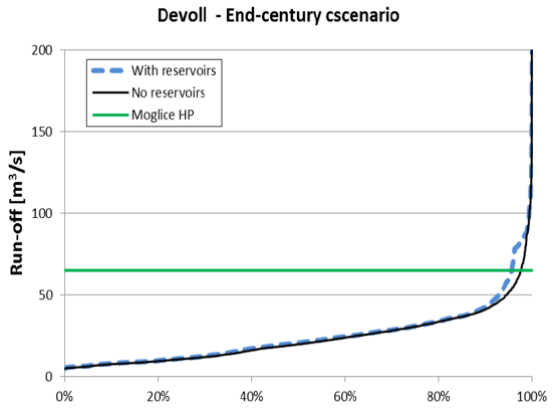

(e)

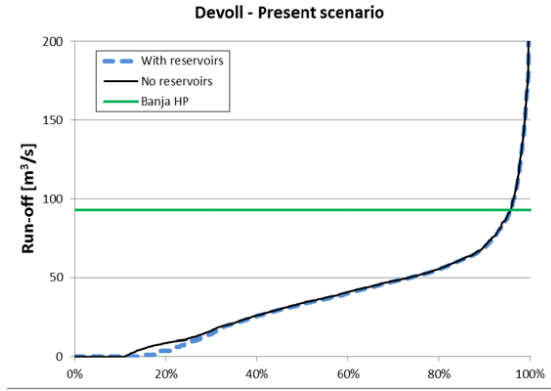

(b)

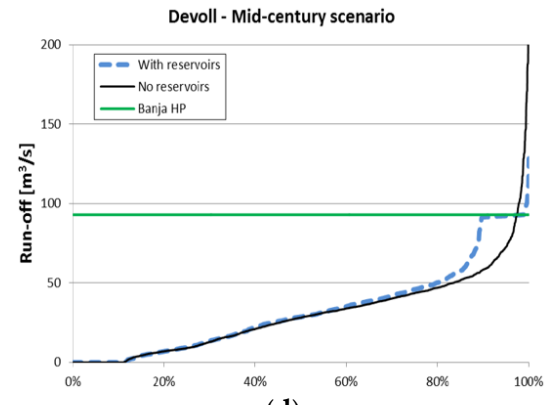

(d)

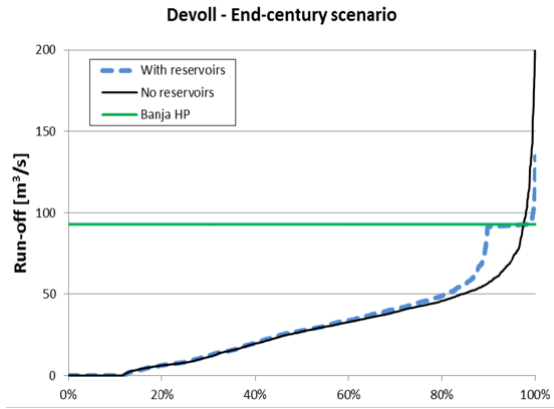

$(\mathbf{f})$

Figure 6. Scenario results presented as flow duration curves (exceedance curves) from Devoll River Basin, under present, mid-century and end of century climatic conditions and irrigation withdrawals as specified in Tables 4 and 5 with and without reservoirs present. The horizontal lines represent turbine capacities of the hydropower plants located close to the control points. $(\mathbf{a}, \mathbf{b})$ refer to present situation at the middle, lower control point and close to the outlet, respectively. (c,d) present results from the mid-century situation at the same control locations, while $(\mathbf{e}, \mathbf{f})$ refer to the end-century situation at the middle, lower control point and close to the outlet, respectively. As there are presently no reservoirs at Devoll River Basin, the graphs in the two upper panels labelled "with reservoir" are simulation results with a hypothetical introduction of reservoirs under the current climatic conditions and level of irrigation. 
Looking into the periodicity of the changes in water availability at Kizilirmak (Figure 7), we can see that it is lowest during the summer, both with and without reservoirs, and the introduction of the reservoirs removes the high flows. The regulation does not increase low flow during the summer at the end of the century. The reservoirs introduce a slight time shift of the low flow occurrences from mid-summer to late summer.

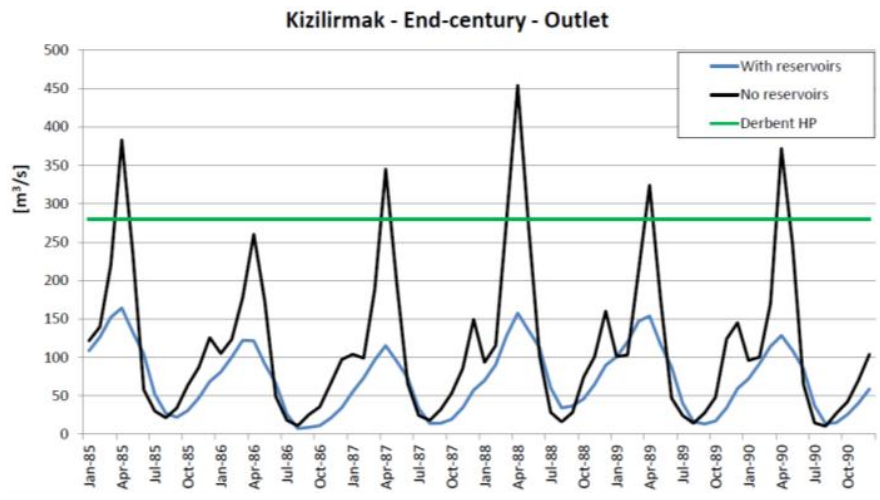

Figure 7. Time series of water flow at the outlet of Kizilirmak River Basin for a selected period re-projected into the end of the century, with and without reservoirs in the basin. The turbine capacity of Derbent HP is drawn as the horizontal line. The full turbine capacity is utilized for only short periods in the situation with no reservoirs.

The utilization time (number of hours per year the power plant operates on full load) of each of the power plants is clearly affected by the reservoirs and the future situation with climate change and increased irrigation withdrawals (Figure 8). For the power producers in the lower parts of Kizilirmak, the presence of the upstream reservoirs reduces the utilization time (Figure 8, left part), and it would have been better for these operators if the upstream reservoirs had not been built. At Devoll, the reservoirs improve the utilization time substantially in the future situations at both control locations. The introduced environmental restrictions with high priority in the lower parts of the basin contribute to the higher utilization time, because they pose limitations on the irrigation withdrawal in the upper part. It should be noted that the energy demand and operation of the reservoirs are modelled very simplistic, and a smarter use of the reservoirs is expected to lead to more beneficial use of the water.

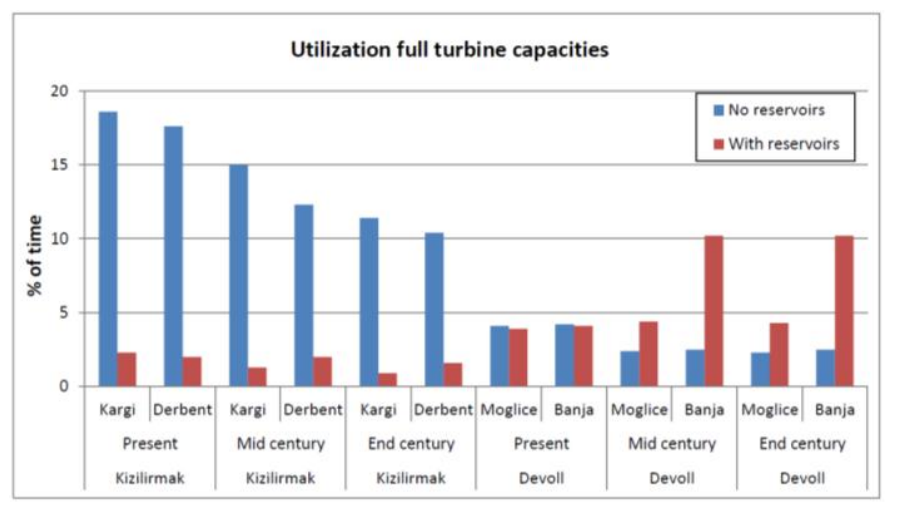

Figure 8. Percentage of time the full turbine capacities are utilized during the present and future situations, with and without reservoirs represented in the model setups.

\subsection{Comparison to Past Research}

A number of studies have analyzed the long-term change in runoff and/or hydropower production due to climate change. The results from [24] include the effects of both a moderate 
climate change and anthropogenic water consumption and indicate large reductions in runoff in the region of our study. The specific results from the Euphrates-Tigris estimate reductions larger than $50 \%$ in the more extreme scenarios, where only Indus (Pakistan) is expected to experience similar large reductions in flow. The work in [23] shows a clear signal that the region of Albania and Turkey will experience flow reduction in the future due to climate change, where the predicted changes are in the range of $20 \%-40 \%$ for the period 2041-2060 compared to the period 1900-1970. The studies by [43-45] on climate change impacts on runoff in Turkey, reviewed by [46], draw two main conclusions. Firstly, there will be large decreases in runoff across much of Turkey by the end of this century, which is in line with our findings at Kizilirmak. Secondly, there will be a spatial variation in the magnitude of the change, with the smallest decreases and possibly increases occurring along the northeastern coast of Turkey. Our results are also in line with the trends found by [47], who simulated the effect of climate change on hydropower production, but did not take into account changes in irrigation withdrawals. The work in [48] simulated Europe's hydropower potential and found that the hydropower potential might be reduced by $25 \%$ or more in south and southeastern European countries. The study of [49] from Alpine Northern Italy predicts an increase in hydropower production in 10 out of 12 months and a decrease in June and July. This is somehow in line with the findings of [50] from the Upper Danube Basin, showing decreased production during summer and increased production in the winter period. Similar results of reduced hydropower production mainly during the summer season have been found in other semi-arid regions, such as in the Yuba River in California, U.S. [51]. The Yuba River is similar to the Devoll River Basin, but with lower water resources availability.

The introduction of new reservoirs represents in some cases, such as at Kizilirmak, a "double-threat" for the downstream hydropower producers, as the reservoir evaporation will reduce the annual volumes of water available downstream, and the regulated flow will allow larger irrigation withdrawals. Reservoirs provide access to water in periods where the unregulated river would have had very little water available. This is often also at the time of the year where the crops' water needs are highest, i.e., from early summer to autumn. The development of the irrigation schemes for the river will directly benefit from the regulated flow of reservoirs. This situation is similar to the management of reservoirs in the California water system, in particular in Yolo County, where strategies that include water savings, diversifying cropping patterns and improved irrigation are necessary to decrease water demands and create conditions for a more balanced water distribution [52]. In Yolo County, there is also heavy reliance on groundwater, which can also contribute to the mix of water supply alternatives for water-scarce conditions. For the hydropower operator, the location of the plants compared to other water consumers is important to consider, as well as the potential risk of new water consuming activities established upstream of your own project.

Even if the purpose of an upstream reservoir is power production, it can potentially reduce the inflow to a downstream plant, due to increased evaporation losses and irrigation withdrawals. A higher degree of regulation provided by upstream reservoirs might be a disadvantage for a downstream hydropower project. As such, hydropower producers might compete internally over water, and a lower degree of regulation in the basin can, in some cases, be beneficial for those plants located in the downstream end. On the other side, if additional withdrawals made possible due to the regulated flow are abandoned, areas downstream of the reservoir can experience higher availability of water.

Looking at the water losses due to reservoir evaporation exclusively, it should be underlined that those "losses" might be beneficial from a society point of view [13] as the benefits of the available water might be far higher than the costs of the water losses due to reservoir evaporation. Balancing these trade-offs might, however, be a delicate management task in water-stressed regions, as it might also involve a transfer of the benefits from one sector to another and also spatially within the basin. The reservoirs improve under certain circumstances the availability of water for irrigation at Kizilirmak, to the disadvantage of hydropower production in the lower end. 


\subsection{Guidance for Future Hydropower Developments}

The production of electricity from hydropower is determined exclusively by water availability, and water cannot be replaced by another fuel. The inter-dependency between water and energy ("water and energy nexus") is also underlined by the fact that the availability of water, at least for private consumption, is also to a large extent determined by the access to electricity for pumping and treatment. In order to analyze the risks of future hydropower investments, all factors possibly affecting the availability of water in the mid- and long-term must be assessed. Based on our study, we find it pertinent to propose some guidelines for where particular caution must be made when assessing the risk of hydropower investments:

- In regions where the predictions of climate change will give lower precipitation, higher temperatures and possibly reduced runoff.

- In parts of the basin where the available resources are threatened by upstream human activities that might consume water, directly or indirectly. The agricultural sector represents, in particular, a threat, due to its potentially large water consumption.

- Where indirect factors affect the water priorities and/or consumption, such as population growth and plans for increased food production.

- Where changes in legislation are expected, potentially affecting increased mandatory releases, e.g., for environmental flow.

Such broad assessments should incorporate technical and participatory processes and can guide planning and decision-making under uncertainty, as has been promoted in other semi-arid regions, like California [51].

\subsection{Sources of Uncertainty}

A number of assumptions and simplifications are made in order to establish a model to represent the river basin processes analyzed in this study, introducing uncertainties to the outcome. There are also uncertainties in the input data, as well as the data used for calibration. Even though WEAP is considered a suitable hydrological model for the purpose of this study, the tool's built-in functions are approximate representations of the processes in the river basins. Important assumptions and limitations affecting the model results are discussed in the following.

Priorities between the different types of water uses (e.g., hydropower versus environmental flow versus irrigation), as well as internally among water uses of similar types (e.g., between irrigation schemes) need to be defined in order to allocate water according to those priorities. We imposed the priorities according to our best available knowledge on the priorities and restrictions set by the authorities in each basin. These priorities for water allocation have implications on the available flow in the lower parts of the basin.

We have limited information about the actual operation, because this is often considered business confidential information. Consequently, the representation in the model introduces uncertainty to the results. The energy demand is modelled in a very simplistic way, and the reservoirs will most likely be operated in a more beneficial way in order to produce more power during periods of high electricity price, leading to larger changes in flows than presented in our figures, especially at Devoll.

The return flow from irrigation back into the river is set uniformly at $20 \%$ of the withdrawal, which is a gross estimate that could be more accurately included with additional on-site information. A higher return flow will reduce the net withdrawal from the river. The limited climatic input data available in the Turkey case also increases the input data uncertainty, in particular for representing a large basin.

The hydraulic routine is simplified, possibly affecting the timing of the water flow (Section 2.1). The implications of this assumption are that simulations of water routing in the system are not included in the routines, and all water entering the system in one time step is at the outflow in the same time step. As such, we believe a monthly time step for the large basin of Kizilirmak and a daily time 
step for the smaller basin of Devoll are appropriate approximate assumptions about water routing in these watersheds.

We used the RCP4.5 for the climate assessment as a moderate future development path assuming some reductions in emissions in the next century. We further used the median of the IPCC model runs as the likely scenario within the different RCP4.5 model runs. We acknowledge that this is just one scenario for the future climate, and using the higher RCP6./RCP8.5 scenarios would probably have decreased available water further.

\section{Conclusions}

We have modelled the effect of climate change and increased irrigation withdrawals on the available water for hydropower production in two semi-arid river basins, i.e., Kizilirmak (Turkey) and Devoll (Albania), and the role of the reservoirs. Key findings from our two case studies are:

- The combined effect of climate change and extended irrigation withdrawals will overall lead to reduced runoff in the rivers. The changes will be far more pronounced at Kizilirmak than Devoll.

- The large reservoirs upstream of Kargi HP and Derbent HP (at Kizilirmak) will enable large irrigation withdrawals. In combination with evaporation from the surface areas, the water available in the lower parts will be reduced compared to the situation if reservoirs had not been present in the basin.

- The irrigation at Devoll is located in the upstream part of the basin, but considered presently to represent a low risk to the downstream power production.

The results are sensitive to the specific river basins and assumptions made in this study, including the defined priorities of water use and the imposed rules of reservoir operation. As such, the results cannot be generalized to other river basins without taking these specifics into consideration.

We recommend that future prospecting hydropower projects include the development of basin-wide hydrological risk assessment plans, taking into consideration all factors affecting the available water resources in the medium and long-term, such as:

- Climate change;

- All consumptive water use and withdrawals potentially affecting the available water resources;

- The role of all reservoirs, even though the purpose of the reservoirs might be non-consumptive;

- The location of the reservoir in the river basin compared to other water uses, such as irrigated agriculture;

- The volume of the increased evaporation from the reservoir surfaces;

- The actual operation of the reservoirs, i.e., timing of the filling and release;

- The priority of water use in the basin, including the introduction of environmental restrictions and other policies changing water use.

Acknowledgments: This paper is based on the results from two master's theses by Jørgen Melhuus Rugelbak and Christian Almestad at the Norwegian University of Science and Technology (NTNU), Department of Hydraulic and Environmental Engineering, Norway, under the supervision of Knut Alfredsen and Tor Haakon Bakken, which is further extended and modified. The study has received financial support via EcoManage, funded by the Research Council of Norway (Contract No. 215934/E20). EcoManage is organized under the research Centre CEDREN (Centre for Environmental Design of Renewable Energy—www.cedren.no). We would like to thank Statkraft for the kind provision of data and information about the case studies, and Prof. Jan Ketil Rød (NTNU) for valuable feedback on the outline of the study, as well as draft versions of the article. We would like to thank three anonymous reviewers for providing very useful feedback on earlier versions of the article.

Author Contributions: Jørgen Mehuus Rugelbak and Christian Almestad did the data collection/compilation, calibration and some of the scenario simulations at Kizilirmak and Devoll, respectively. Marisa Escobar contributed to editing of the paper, and brought in experience from California. Knut Alfredsen provided a constructive critique of the design of the study and the statistical results. Steven Micko assisted in the preparation of the graphs and maps. Tor Haakon Bakken carried out scenario simulations without reservoirs in the basins and did the writing.

Conflicts of Interest: The authors declare no conflict of interest. 


\section{References}

1. Rockström, J.; Steffen, W.; Noone, K.; Persson, Å.; Chapin, F.S.; Lambin, E.; Lenton, T.M.; Scheffer, M.; Folke, C.; Schellnhuber, H.; et al. A safe operating space for humanity. Nature 2009, 461, 472-475. [CrossRef] [PubMed]

2. Jaramillo, F.; Destouni, G. Comment on “Planetary boundaries: Guiding human development on a changing planet". Science 2015, 348, 1217. [CrossRef] [PubMed]

3. Bates, B.C., Kundzewicz, Z.W., Wu, S., Palutikof, J.P., Eds.; Climate Change and Water, Technical Paper of the Intergovernmental Panel on Climate Change; IPCC Secretariat: Geneva, Switzerland, 2008; p. 210.

4. Edenhofer, O., Pichs-Madruga, R., Sokona, Y., Seyboth, K., Matschoss, P., Kadner, S., Zwickel, T., Eickemeier, P., Hansen, G., Schlömer, S., et al, Eds. IPCC Special Report on Renewable Energy Sources and Climate Change Mitigation; Cambridge University Press: Cambridge, UK; New York, NY, USA, 2011.

5. Edenhofer, O., Pichs-Madruga, R., Sokona, Y., Farahani, E., Kadner, S., Seyboth, K., Adler, A., Baum, I., Brunner, S., et al, Eds. Climate Change 2014: Mitigation of Climate Change. Contribution of Working Group III to the Fifth Assessment Report of the Intergovernmental Panel on Climate Change; Cambridge University Press: Cambridge, UK; New York, NY, USA, 2014.

6. Charting the Upsurge in Hydropower Development; World Energy Council: London, UK, 2015.

7. Lelieveld, J.; Evans, J.S.; Fnais, M.; Giannadaki, D.; Pozzer, A. The contribution of outdoor air pollution sources to premature mortality on a global scale. Nature 2015, 525. [CrossRef] [PubMed]

8. ICOLD World Register of Dams. 2014. Available online: http://www.icold-cigb.org/GB/World_register/ world_register.asp (accessed on 14 June 2014).

9. Bakken, T.H.; Kjosavik, F.; Killingtveit, Å.; Alfredsen, K. Are reservoirs water consumers or water collectors? Reflections on the water footprint concept applied on reservoirs. J. Water Resour. Manag. 2015, 29, 4919-4926. [CrossRef]

10. Destouni, G.; Jaramillo, F.; Prieto, C. Hydroclimatic shifts driven by human water use for food and energy production. Nat. Clim. Chang. 2013, 3, 213-217. [CrossRef]

11. Shiklomanov, I.A. Appraisal and Assessment of World Water Resources. Water Int. 2000, 25, 11-32. [CrossRef]

12. Jaramillo, F.; Destouni, G. Local flow regulation and irrigation raise global human water consumption and footprint. Science 2015, 350, 1248-1251. [CrossRef] [PubMed]

13. Strzepek, K.M.; Yohe, G.W.; Tol, R.S.J.; Rosegrant, M. The value of the Aswan high Dam to the Egyptian economy. Ecol. Econ. 2008, 66, 117-126. [CrossRef]

14. Kadigi, R.M.J.; Mdoe, N.S.Y.; Ashimogo, G.C.; Morardet, S. Water for irrigation or hydropower generation? Complex questions regarding water allocation in Tanzania. Agric. Water Manag. 2008, 95, 984-992. [CrossRef]

15. Gleick, P.H. Water Use. Annu. Rev. Environ. Resour. 1994, 28, 275-314. [CrossRef]

16. Mekonnen, M.M.; Hoekstra, A.Y. The blue water footprint of electricity from hydropower. Hydrol. Earth Syst. Sci. 2012, 16, 179-187. [CrossRef]

17. Bakken, T.H.; Killingtveit, Å.; Engeland, K.; Alfredsen, K.; Harby, A. Water consumption from hydropower plants-Review of published estimates and an assessment of the concept. Hydrol. Earth Syst. Sci. 2013, 17, 3983-4000. [CrossRef]

18. Bakken, T.H.; Modahl, I.S.; Engeland, K.; Raadal, H.L.; Arnøy, S. The life-cycle water footprint of two hydropower projects in Norway. J. Clean. Prod. 2016, 113, 241-250. [CrossRef]

19. Tremblay, A.; Tardif, S.; Strachan, I.B.; Turpin, C. Environmental Effects. Studying the Net Evaporation Effect from the Eastman-1 Reservoir. Available online: http://dpue.energ.pub.ro/files/reviste/ HYDRO/HYDRO_Jun_2014.pdf (accessed on 9 March 2016).

20. Catrinu, M.D.; Knudsen, J.K.; Solvang, E. Perspectives on Hydropower's Role to Balance Non-Regulated Renewable Power Production in Northern Europe; SINTEF Report TR A7107; SINTEF Energy Research: Trondheim, Norway, 2011.

21. Gabrielsen, R.H., Grue, J., Eds.; Norwegian Energy Policy in Context of the Global Energy Situation; Norwegian Academy of Science and Letters: Oslo, Norway, 2012.

22. Wisser, D.; Frolking, S.; Hagen, S.; Bierkens, M.F.P. Beyond peak reservoir storage? A global estimate of declining water storage capacity in large reservoirs. Water Resour. Res. 2013, 49, 5732-5739. [CrossRef]

23. Milly, P.C.D.; Dunne, K.A.; Vecchia, A.V. Global pattern of trends in streamflow and water availability in a changing climate. Nature 2005, 438, 347-350. [CrossRef] [PubMed] 
24. Haddeland, I.; Heinke, J.; Biemans, H.; Eisner, S.; Flörke, M.; Hanasaki, N.; Konzmann, M.; Ludwig, F.; Masaki, Y.; Schewe, J.; et al. Global water resources affected by human interventions and climate change. Proc. Natl. Acad. Sci. USA 2014, 111, 3251-3256. [CrossRef] [PubMed]

25. Schewe, J.; Heinke, J.; Gertena, D.; Haddeland, I.; Arnell, N.W.; Clarke, D.B.; Dankers, R.; Eisner, S.; Fekete, B.M.; Colón-González, F.J.; et al. Multimodel assessment of water scarcity under climate change. Proc. Natl. Acad. Sci. USA 2014, 111, 3245-3250. [CrossRef] [PubMed]

26. Betts, R.A.; Golding, N.; Gonzalez, P.; Gornall, J.; Kahana, R.; Kay, G.; Mitchell, L.; Wiltshire, A. Climate and land use change impacts on global terrestrial ecosystems and river flows in the HadGEM2-ES Earth system model using the representative concentration pathways. Biogeosciences 2015, 12, 1317-1338. [CrossRef]

27. Trenberth, K.E. Changes in precipitation with climate change. Clim. Res. 2011, 47, 123-138. [CrossRef]

28. Yates, D.; Sieber, J.; Purkey, D.; Huber-Lee, A. WEAP21-A Demand-, Priority-, and Preference-Driven Water Planning Model. Water Int. 2005, 30, 487-500. [CrossRef]

29. Mehta, V.; Yates, D. Integrated Water-Energy-Emissions Analysis: Applying LEAP and WEAP Together in California. Stockholm Environment Institute (SEI) Policy Brief 2012. Available online: http://www.sei-international.org/mediamanager/documents/Publications/SEI-PolicyBrief-Integrated WaterEnergyEmissionsAnalysis-2012.pdf (accessed on 10 January 2016).

30. Rugelbak, J.M. Analysis of Water Consumption in Kizilirmak Using the WEAP Model. Effects of Climate Change and Increased Water Use. Master's Thesis, Norwegian University of Science and Technology, Trondheim, Norway, 2014.

31. Almestad, C. Modelling of Water Allocation and Availability in Devoll River Basin, Albania. Master's Thesis, Norwegian University of Science and Technology, Trondheim, Norway, 2015.

32. Statkraft. Web-Site Describing Kargi HP. 2015. Available online: http://www.statkraft.com/energy-sources / Power-plants/Turkey/kargi-hydropower-plant/ (accessed on 10 January 2016).

33. LandScan Dataset. Population Statistics. 2008. Available online: http://web.ornl.gov/sci/landscan/ index.shtml (accessed on 10 August 2015).

34. Norconsult: EISA Report (Executive Summary). 2011. Available online: http://www.dhp.al/images/pdf/ Downloads/September_2011_Executive_Summary_ESIA_Report_English.pdf (accessed on 10 January 2016).

35. World Bank, Population Statistics. 2015. Available online: http://datatopics.worldbank.org/hnp/ popestimates (accessed on 10 January 2016).

36. Bakken, T.H.; Rugelbak, J.; Escobar, M.; Sorman, A.Ü.; Alfredsen, K.; Killingtveit, Å. The effects of change in climate and irrigation practice on the hydropower resources in Kizilirmak River Basin, Turkey. In Proceedings of the ICOLD 20th Congress / ICOLD 83rd Annual Meeting Symposium Hydropower'15, Stavanger, Norway, 13-20 June 2015.

37. Shaw, E.M.; Beven, K.J.; Chappell, N.A.; Lamb, R. Hydrology in Practice, 4th ed.; Spon Press: London, UK, 2011.

38. Beven, K. Rainfall-Runoff Modelling: The Primer; Wiley-Blackwell: Hoboken, NJ, USA, 2012.

39. Annex I: Atlas of Global and Regional Climate Projections. In Climate Change 2013: The Physical Science Basis. Contribution of Working Group I to the Fifth Assessment Report of the Intergovernmental Panel on Climate Change; Cambridge University Press: Cambridge, UK; New York, NY, USA, 2013.

40. Teutschbein, C.; Seibert, J. Bias correction of regional climate model simulations for hydrological climate-change impact studies: Review and evaluation of different methods. J. Hydrol. 2012, 456, 12-29. [CrossRef]

41. Lafon, T.; Dadson, S.; Buys, G.; Prudhomme, C. Bias correction of daily precipitation simulated by a regional climate model: a comparison of methods. Int. J. Climatol. 2013, 33, 1367-1381. [CrossRef]

42. Moriasi, D.N.; Arnold, J.G.; Van Liew, M.W.; Bingner, R.L.; Harmel, R.D.; Veith, T.L. Model evaluation guidelines for systematic quantification of accuracy in watershed simulations. Am. Soc. Agric. Biol. Eng. 2007, 50, 885-900.

43. Giannakopoulos, C.; Sager, P.L.; Bindi, M.; Moriondo, M.; Kostopoulou, E.; Goodess, C. Climatic changes and associated impacts in the Mediterrranean resulting from $2{ }^{\circ} \mathrm{C}$ global warming. Glob. Planet. Chang. 2009, 68, 209-224. [CrossRef]

44. Sen, O.L.; Unal, A.; Kindap, T.; Bozkurt, D.; Dalfes, H.N.; Karaca, M. Past and future changes in the discharges of the Euphrates and Tigris Rivers. In Proceeding of the EGU General Assembly Conference, Vienna, Austria, 2-7 May 2010. 
45. Yilmaz, K.; Yazicigil, H. Potential impacts of climate change on Turkish water resources: A review. In Climate Changes and Its Effects on Water Resources; Baba, A., Tayfur, G., Gündüz, O., Howard, K.W.F., Friedel, M.J., Chambel, A., Eds.; NATO Science for Peace and Security Series C: Environmental Security; Springer Netherlands: Dordrecht, The Netherlands, 2011; Volume 3, pp. 105-114.

46. Lawrence, D.; Haddeland, I. Catchment-Based Modelling of Climate Change Impacts on Runoff in Southeast Europe; NVE Report 25/2012; Norwegian Water Resources and Energy Directorate (NVE): Oslo, Norway, 2012.

47. Hamududu, B.; Killingtveit, A. Assessing Climate Change Impacts on Global Hydropower. Energies 2012, 5, 305-322. [CrossRef]

48. Lehner, B.; Czisch, G.; Vassolo, S. The impact of global change on the hydropower potential of Europe: A model-based analysis. Energy Policy 2005, 33, 839-855. [CrossRef]

49. Ravazzani, G.; Dalla Valle, F.; Mendlik, T.; Galeati, G.; Gobiet, A.; Mancini, M. Assessing climate impacts on hydropower production of Toce Alpine basin. In Engineering Geology for Society and Territory: Climate Change and Engineering Geology: 1; Lollino, G., Manconi, A., Clague, J., Shan, W., Chiarle, M., Eds.; Springer International Publishing: Berlin/Heidelberg, Germany, 2015; pp. 9-12.

50. Koch, F.; Prasch, M.; Bach, H.; Mauser, W.; Appel, F.; Weber, M. How Will Hydroelectric Power Generation Develop under Climate Change Scenarios? A Case Study in the Upper Danube Basin. Energies 2011, 4, 1508-1541. [CrossRef]

51. Mehta, V.K.; Rheinheimer, D.E.; Yates, D.; Purkey, D.R.; Viers, J.H.; Young, C.A.; Mount, J.F. Potential impacts on hydrology and hydropower production under climate warming of the Sierra Nevada. J. Water Clim. Chang. 2011, 2, 29-43. [CrossRef]

52. Mehta, V.K.; Haden, V.R.; Joyce, B.A.; Purkey, D.R.; Jackson, L.E. Irrigation demand and supply, given projections of climate and land-use change, in Yolo County, California. Agric. Water Manag. 2013, 117, 70-82. [CrossRef]

(C) 2016 by the authors; licensee MDPI, Basel, Switzerland. This article is an open access article distributed under the terms and conditions of the Creative Commons by Attribution (CC-BY) license (http://creativecommons.org/licenses/by/4.0/). 